\title{
Social Movement and Political Power: The Success of the United Telukjambe United Farmers Union (STTB) in the Resolution of Agrarian Conflicts in Karawang Regency in 2013-2017
}

\author{
Ana Sabhana Azmy ${ }^{1}$, and Yodi Tri Hoetomo ${ }^{2}$ \\ \{anashabana.azmi@uinjkt.ac.id ${ }^{1}$,yodi.hoetomo14@mhs.uinjkt.ac.id²\} \\ Universitas Islam Negeri Syarif Hidayatullah Jakarta, Indonesia ${ }^{12}$
}

\begin{abstract}
This paper analyses the role of the Telukjambe United Farmers Union (STTB) in the successful resolution of agrarian conflicts in Karawang Regency in 2016-2017. The purpose of this study was to determine the role and supporting factors of the success of STTB in resolving conflicts that occurred in the District of Telukjambe Barat, Karawang Regency, West Java Province. Conflicts involving Telukjambe farmers and the Pertiwi Lestari Company (PTPL) can be traced historically. This research was conducted with literature study, documentation and interviews with relevant sources. We see that the role of STTB is very significant in successfully resolving conflicts that occur, where STTB is the political power possessed by the Telukjambe farmers in handling conflicts that occur with PTPL. With the existing limitations, STTB in the course of this conflict made efforts to accommodate the hopes and demands of farmers to end with the creation of solutions that benefit both parties.
\end{abstract}

Keywords: Social Movement, Interset Group, Agrarian Conflict, Farmers Union.

\section{Introduction}

Indonesia is one of the largest archipelagic countries in the world consisting of 17,504 islands and is an area surrounded by a ring of fire, so that Indonesia has many volcanoes and frequent earthquakes. On the other hand, the condition of land in Indonesia is rich in natural resources and the soil is quite fertile so that all types of plants can grow well. This makes Indonesia an agrarian country where the majority of its people work as farmers for survival[1].

Nowadays Indonesia's status as an agrarian country has begun to shift to an industrial state, due to the trend of developing countries that follow the flow of developed countries in terms of strengthening the industrial sector. Previously primary production from agricultural products dominated but shifted to secondary production with the rise of the manufacturing industry. Likewise, the land designated for agricultural production is turned into land for manufacturing production, which is to develop industrial estates in various regions.

The impact of this shift caused many agrarian conflicts in Indonesia, where the land used by farmers was converted to private land. Conflict caused by the conflict between two individuals or between groups due to differences in interests, in this case agrarian conflicts often occur due to compensation given by the government or private parties who dispute against farmers over their land not in accordance with what they should get. 
One agrarian conflict that occurred in Indonesia was an agrarian conflict in Karawang Regency in 2013, which is a land dispute between West Telukjambe farmers and Pertiwi Lestari Company (PTPL). Conflicts between West Telukjambe farmers and PTPL arose when an area of 791 hectares that had been cultivated by farmers for generations since 1962, was established as state land in 1973 and one year later the Right to Cultivate (HGU) on behalf of Tanjung Krisik Makmur. According to farmers, some have played with the law because in 1974 the HGU was issued without transfer and compensation to the farmers, then in 1998 a certificate of building rights was issued on behalf of Pertiwi Lestari Company namely Right to Build (HGB) Certificate No. 5 (Margamulya), Certificate No. 11 (Wanajaya), and Certificate No. 40 (Sukaluyu) [2].

The outbreak of land disputes between Telukjambe farmers and PTPL began in 2013 where PTPL parties claimed 791 hectares of land spread across three villages, namely Wanajaya, Margakarya and Margamulya villages, and reduced heavy equipment on land owned by farmers. In the activities carried out by the PTPL, the farmers did not know anything about their land that had been taken over by the PTPL and finally the farmers also resisted by protesting. They consider PTPL to act arbitrarily because it does not involve farmers in the process of granting land tenure licenses.

Land conflicts that occur between West Telukjambe farmers and the Pertiwi Lestari Company can be resolved in 2017 where there is a solution that benefits both parties, and the main actor in the successful resolution of the conflict that benefits the Telukjambe farmers is the United Telukjambe Farmers Union (STTB). STTB emerged as an accumulation of farmers restlessness over the conflict, STTB was born in 2013 and is a group consisting of residents of West Telukjambe farmers, especially farmers who are in conflict with PTPL, against the background of the same boat-unilateral sense of PTPL actions. STTB is a symbol of the struggle of West Telukjambe farmers in fighting for land that they have managed hereditary after the 1960 agrarian reform.

Many land conflicts that occur in Indonesia between the people and private companies have a tendency, where the people are positioned as a party that is very weak in the eyes of the law so that if there is a conflict, it is unlikely to be able to fight. Therefore, the West Telukjambe farmers formed the United Telukjambe United Farmers Union (STTB) as a forum for the struggle to seek justice and demand the rights of the farmers, in this case they both felt as oppressed and marginalized people. STTB can be a representation of the political power possessed by farmers because the union is an interest group, which is a group of people who have similar characteristics, attitudes, beliefs, goals and agree on themselves to enter into an association or organization in order to achieve goals.

\section{Methodology}

Tthis research analyzes the success of STTB in its completionagrarian conflict between farmers of Margamulya and Wanajaya Villages with PT. Pertiwi Lestari. The role is seen from STTB activities that focus from the beginning of the conflict, namely in 2013 until the end of the conflict in 2017, especially through the articulation channels of interest used by STTB. In this research there are also factors supporting the success of STTB in resolving conflicts that occur. 
In this research, the method of collecting data related to the chronology of agrarian conflicts that occurred between Telukjambe farmers and PT Pertiwi Lestari, and the role of STTB in resolving these conflicts also conducted in-depth interviews with actors involved in conflicts such as Budiono as Humas GKTMTB (Association of Unified Telukjambe Farmers Group), Deden as Chairperson of SETAKAR (Karawang Farmers Union), Dedi as Chairperson of LBH GMBI (Legal Aid Foundation for the Indonesian Lower Movement), Inggar as a caretaker of the BMPAN (Youth National Enforcement Enforcement Commission), and Dedi as Chair of the LBH GMBI (Legal Aid Foundation for the Indonesian Lower Movement), Inggar as a caretaker of the BMPAN (National Youth Enforcement Commission), and Wagito as Head of PMP BPN Karawang (Head of Land Management Division of the Land Affairs Agency of Karawang Regency).

\section{Research Result and Discussion}

The results and discussion in this study will be explained more fully as follows:

\subsection{The Role Of United Union Of Telukjambe Farmers (Sttb) In Conflict}

There are tactics or strategies of interest groups to reach influential people, one of them is through demonstration and violence channels. Demonstration is one of political participation carried out by means of protesting in public and such actions are common in democratic countries and acts of violence such as riots or clashes, and killings can also be used by interest groups as a means of reaching influential people [3].

STTB's role in the dynamics of the conflict using the articulation channel of interest in channelling its demands, first through demonstrations. STTB demonstrated 10 times during the conflict, namely in 2013 and 2014 one demonstration, then 2 demonstrations and 1 long martch in 2015, then in 2016 there were 2 demonstrations and in 2017 STTB held 1time protests, 1time long march, and 1time theatrical action which is the act of self-grave.

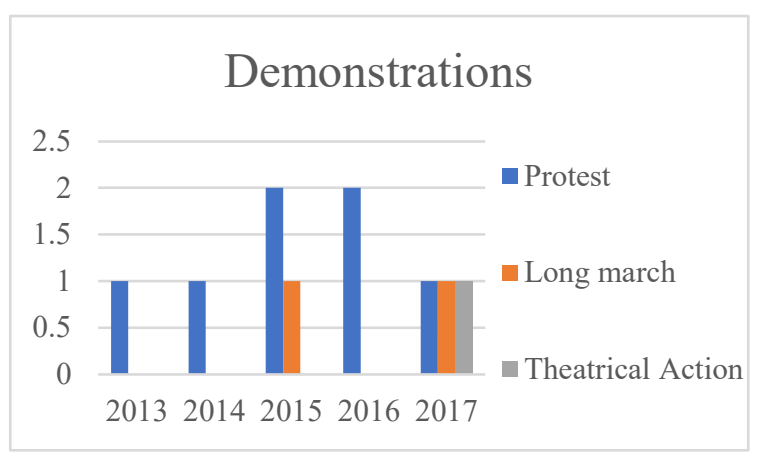

Fig 1. Demonstration channel used by STTB

The struggle of the STTB via the demonstration channel to the summit on April 25, 2017. After all the efforts that have been made by farmers still have not produced results related to the conflict that is happening to them. In another place there was an action taken by the 
Kendeng farmers in Blitar Regency, namely a theatrical action where they took a cast leg action on March 13, 2017. STTB was inspired by the action and carried out a similar action by carrying out a self-grave carried out for 7 consecutive days. participate. This action is a symbol of the death of justice because the government is not at all serious about taking sides with the Telukjambe farmers [4].

Finally, on May 8, 2017 President Joko Widodo gave certainty that he would localize all Telukjambe farmers in conflict with PTPL. The policy was realized on November 1 with the issuance of a certificate of social forestry forest utilization permit. After eight demonstrations, two long marches, and one extraordinary action, namely the self-grave action, the struggle of the STTB through the demonstration ended because after the self-grave action was carried out, solutions related to conflicts experienced by the Telukjambe farmers gradually experienced a bright spot, namely by achieving demands farmers, namely the replacement of land by giving the certificate.

STTB's role as a group of interests uses many demonstrations in channelling its demands to PTPL, local and central government. This channel has many obstacles in its journey because the channel has been used for a long time, but it only got success after four years of use. The strategy carried out by STTB in conducting demonstrations is creative enough to get attention such as long march, and theatrical action, namely the grave action. This is a factor in the successful use of demonstrations as an articulation channel for STTB interests so that they can get public and central government attention. the farmers agreed to the decision and finally the self-grave action was stopped.

In addition to the use of demonstration channels, STTB also uses channels of violence with frequent clashes between farmers and the company. Many minor clashes occurred in 2013 to 2015 between farmers and Pertiwi Lestari Company who entered heavy equipment for the construction of trans roads. The peak of the clash occurred on October 11, 2016 between farmers versus PTPL security guards and the police. PTPL forced farmers to leave the conflict zone by carrying out mass evictions, farmers in the lure were given compensation money with a value of 30 million, but the farmers did not heed it and the clashes were inevitable. Physical clashes such as acts of violence carried out by both sides caused many to be injured. The day after the clash took place, police officers sought scattered farmers and arrested them. The total police arrested 100 farmers and then secured 36 who were suspected [5].

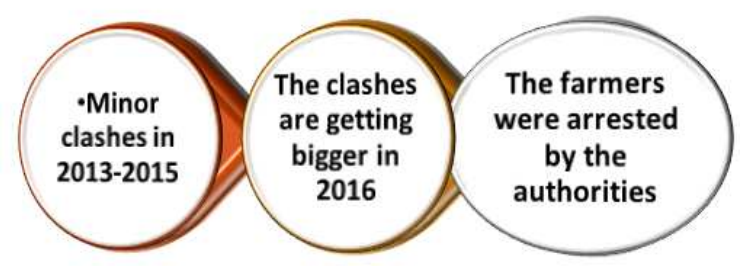

Figure 2.Violence channel used by STTB

Based on previous explanation, this channel is very ineffective in obtaining results that are in accordance with what the STTB wants. Clashes and acts of violence even harm the STTB because it always ends with the arrest of farmers by the police and results in the reduced human resources owned by the STTB.

There are other channels namely institutions such as legislative bodies, cabinet and bureaucracy where the use of these channels is by lobbying tactics. In addition there are 
formal channels that are used by interest groups, namely the mass media that aims as a means of communicating and channeling various demands or interests [6].

Then STTB used other institutional channels through lobbying actions to the government, Then ArisWiyono as the Board of Trustees of the STTB explained that the Telukjambe farmers had agreed to years of criminalization by PTPL and wanted to ask for legal assistance related to that matter. Indonesian Legislative Assembly of member faction nuarPrihatin explained that PKB would try hard to fight for the Telukjambe farmers who were criminalized by PTPL. Related to the criminalization of farmers, F-PKB will discuss and examine further related conflicts that were carried out before moving by coordinating to ask for help Karawang members to go directly to the location of the conflict. F-PKB has an autonomous farm gate that will support the Telukjambe farmers to support the law as a companion to criminalized farmers, and F-PKB will move to discuss this issue in which all male, female, and child farmers have been victims of this conflict. Ida as the leader of the faction stated that the FPKB would instruct members in the House of Representatives Commission II to move and immediately contact the relevant parties so that they could find a solution for the farmers. Concluding from this visit, PKB Faction provided social assistance to STTB and requested that this conflict be resolved immediately.

On April 10, 2017 STTB again lobbied with an audience with the Indonesia Legislative Assembly Commission II in the Republic of Indonesia Parliament Building. The hearing was opened at 12.18 West Indonesia Time where the audience discussed the appearance of aspirations for input and explanations from the STTB supported by the Indonesia Legislative Assembly Commission II providing the scope of tasks related to land and agrarian reform. After explaining the chronology of the conflict, the House of Representatives Commission II decided to conduct a working visit to a conflict meeting with PTPL, the Minister of Agrarian Affairs, the Minister of Environment, local Government, and the Karawang Police Chief on 17 April, 2017. After a working visit and a meeting with related parties, the House Commission II RI decided that the PTPL building rights was frozen because it was building public facilities and had to be demolished. Indonesia legislative assembly Commission II through the Ministry of Home Affairs sent to the Regional Government to follow up on the PTPL and guarantee that the farmers and residences that have been evicted [7].

It can be seen in this discussion about STTB as an interest group using institutional channels through lobbying and hearings. The use of this channel is deemed ineffective because it does not require a lot of disagreement that occurs, as evidenced by the results of the work report of the House of Representatives commission II, namely the freezing of PTPL Building rights and cultivators of cultivated land, as previously it cannot be moved by PTPL. STTB in this case doesn't need to be questioned anymore because the relevant lobby still held a rally on April 9, 2017 and carried out a grave action after a week of work visits by Commission II of the Indonesian Legislative Assembly.

STTB also uses other formal channels namely mass media. The mass media channel in this case has links with other channels that are used by STTB, especially the demonstration channel because the mass media functions to reproduce the STTB movement so that it gets people's attention. The mass media has a stake in the success of the STTB in resolving this conflict. As on 8 may 2017, President Joko Widodo stated that all conflicting farmers will be localized to the new land, then on 10 May 2017, a Minister of Agrarian and Spatial Planning decision will emerge that only 92 heads of households will be localized. The decision was not accepted by STTB because the President promised to relocate all farmers in conflict with PTPL. As a result of this decision, news emerged in the mass media that STTB would return to the next grave by deploying 300 coffins. After the threat information came to the 
government, eventually the localized farmers increased to 350 family heads. After hearing this, STTB cancelled its intention to return to action.

\subsection{Supporting Factors For The Success of STTB In Resolving Conflicts}

One of the success factors of STTB is the presence of member militancy in the movement itself. To maintain member militancy, STTB in its breath of movement uses the enforcement of the 1945 Constitution Article 33 Paragraph 3 "The earth and water and natural resources contained therein are controlled by the state and used for the greatest prosperity of the people" and the concept of true agrarian reform in UUPA No.5 / 1960 article 46 "The right to open land and collect forest products can only be owned by Indonesian citizens andregulated by Government Regulation" as the basis for STTB in fighting for the land [8].

Seeing the militancy of the STTB, it can be related to Robert Ted Gurr's relative deprivation concept that farmers want to change the existing reality by creating a social movement that is STTB as a place of struggle. In the concept of relative deprivation, social movements arise from the motivations of individuals due to not achieving their expectations, in this case STTB appears as their hopes in fighting for land that they have been working on to return to normal. Militancy increasingly arises because of the feelings of the farmers who jointly feel the injustice committed by PTPL, making the STTB movement as a more solid social movement and finally finding achievements according to farmers' expectations when forming the STTB [9]. Then STTB as a social movement has passed the stage where the emergence of a leader who then unites the Telukjambe farmers in a union namely STTB, the leader is Maman Nuryaman.

Based on this point, it can be seen that every movement carried out by STTB in demanding their rights, there is militancy as a driving force for farmers in fighting for land that has been claimed by PTPL. The initial foundation of militancy has been formed, which arises from a sense of farmers' solidarity due to land grabbing, then Militancy is strengthened by instilling Article 33 of the 1945 Constitution and the BAL 1960 as the STTB ideology so that it is always attached to every breath of movement and also other factors are the leadership figure in the body of the STTB. Militancy is very important for Telukjambe farmers in dealing with conflict, which is fighting the fear of PTPL intimidation that has been experienced by farmers and also does not give up accepting compensation money given by PTPL because the replacement money is not very commensurate.

The success of the STTB in resolving the conflict cannot be separated from the support of these supporting actors namely the Youth Commission of National Mandate Enforcement (BM PAN), the Indonesian Lower Peoples Movement (GMBI), LBH Bandung, LBH contrast, Karawang Farmers Union (SETAKAR), National Farmers Union (STN), Muhamadiyah Central Leadership, Dompet Dhuafa, and Lazizmu In the conflict, there were three important actors who supported the success of the STTB in resolving the conflict, namely BM PAN, GMBI, and STN BM PAN supported while the farmers remained in the conflict location. such as providing moral support by always assisting farmers against PTPL's appropriation, in this case moral support becomes a very important thing so that farmers feel their struggle is not carried out on their own, where the community also supports their struggle, it can become a motivating motor the farmers to struggle with the conflict [10].

The next important actor is to support the farmers in facing the criminalization committed by PTPL in the conflict, namely the Lower Indonesian Community Movement and the Legal Aid Institution they support. In the clash that occurred on October 11, 2016, there were many farmers who were hunted and arrested, counted 100 farmers were arrested and then 35 farmers 
were secured by the police and narrowed down to 11 farmers who were determined to be suspects. End of the struggle of STTB and the LBH Alliance initiated by Dadi Mulyadi in the case of farmer criminalization ended on March 9, 2017, where a verdict was read out by the panel of judges at the Karawang District Court. The panel of judges acquitted five peasants and six other peasants convicted with an average sentence of less than one-year imprisonment in the sense that all farmers would not get a prison sentence [11].

Then there is the National Farmers Union as one of the important actors related to the success of the STTB in resolving conflicts. In addition to giving farmers who are displaced in Jakarta an asylum at the National Farmers Union Office for 22 days, STN also always accompanies the STTB movement in resolving conflicts that occur. STN has a role in finalizing STTB as a professional organization, namely by holding focus group discussions related to the Farmers movement strategy and inviting STTB representatives to attend the FGD. Other support is also very meritorious for STTB so that it can resolve conflicts that occur, such as Lazizmu who provide compensation in the form of money and clothing when farmers are displaced in Jakarta and Dompet Dhuafa, namely building mosques in replacement land locations so farmers can worship comfortably.

STTB's journey in the conflict between farmers and PTPL cannot be separated from interactions with the government where the interaction that occurs is STTB as the prosecutor and the government as policy maker. This is in accordance with David Easton's (1953) political system cycle, where the STTB is positioned as inputs which is a party that provides demands for the Karawang regency government policy because it has issued HGB No.5 / Margamulya Village with Measurement Letter No.27.03.00001 dated April 14, 2010 covering 3,264 .125 m2, HGB No.11 / Wanajaya Village with Measurement Letter No. 03.20,00011 dated January 22, 1998 covering 2,931,062 m2, and HGB No.30 / Wanajaya Village with Measurement Letter No.27.03.00001 dated March 27, 2009 covering an area of 1,698,808 m2 in Telukjambe Barat District, Karawang Regency on behalf of the Pertiwi Lestari Company [12].

At the end of the conflict, there are two outputs produced by the government to resolve the conflict that occur in this case the two outputs have differences but are interrelated. The first output in terms of land distribution is very small, but the land belongs to STTB farmers who are relocated to the area and is permanent as a sign of conflict peace given by PTPL to STTB. In contrast to the second output where land given by the government through the issuance of SK.5320 / MENLHK-PSKL / PKPS / PSL.0 / 10/2017 namely Social Forestry Forestry Permit (IPHPS) where farmers are provided land to produce forest and agricultural products with a period of granting land for 35 years and can be extended through evaluation. The land cannot be owned by individuals because it is communal in the sense of jointly owned land, that is, each head of the family who is given IPHPS is given an area of two hectares to produce agricultural production with the division of land carried out by consensus agreement [13].

In this point, government interaction with STTB is dominated by input and output.[14] In this case the government is seen as an antagonist in the conflicts that occur where they tend to provide policies that burden the STTB. But at the end of the conflict it can be seen that the government also helped in resolving the conflict and was proactive in tending to the demands of farmers. We highlights that the conflict experienced by STTB, has the right timing where the central government is implementing an agrarian reform program so that conflicts that occur with PTPL can be resolved immediately after the output is generated.

President Joko Widodo in his nawacita promise to allocate around 21.7 million hectares in the 2015-2019 National Medium-Term Development Plan (RPJMN) to implement agrarian 
reform. Conflict between STTB and PTPL is one of the government's priorities, namely the land legalization of assets which is the object and at the same time an arena for conflicting claims between community groups and corporations. The allocated land is intended as a replacement land with the IPHPS given so that the agrarian conflict problem can be resolved properly [15].

Based on this chapter, it can be seen that there are two dominant factors in the success of the STTB in resolving the conflicts that occur. First, the struggle of STTB through various articulation channels used can touch policy makers, namely the government. Second, the agrarian reform strategy policy owned by the government is the key in resolving conflicts that occur with a solution for both parties to the conflict. These two factors are interrelated in the resolution of conflicts that occur, where if STTB is not formed, farmers do not have a container of aspirations in asserting their political rights, the conflict ends with farmers taking rope money that is not commensurate with what has been taken from them. Likewise, from the government, if the government does not have more attention, that is, it does not have an agrarian reform policy, the resulting output will not be in accordance with what the STTB wants.

\section{Conclusions}

The presence of the United Telukjambe United Farmers Union (STTB) can be seen as a manifestation of the struggle of the Telukjambe Farmers to defend land for claims made by the Pertiwi Lestari Company. We see a number of STTB's roles in the successful resolution of conflicts that occur; First, the use of demonstration channels, especially the grave action carried out by STTB so that the government pays attention to the demands of the masses. Second, the use of mass media channels as supporters of the demonstration channel. Third, the use of other institutional channels, through lobbying and hearings. STTB held a meeting with F-PKB Indonesian Legislative Assembly RI and Indonesian Legislative Assembly RI Commission II although, the results of the channel were not effective. Fourth, the use of channels through acts of violence between Telukjambe farmers and PTPL. However, the channel did not produce results in conflict resolution. Can be analysed STTB has a very significant role in the success of resolving conflicts that occur, where STTB maximizes the articulation channels of interests that are owned although it is quite limited.

There are supporting factors for the success of STTB in resolving conflicts that occur. First, the sense of militancy that STTB members have. The sense of militancy became the driving force of the STTB so that the struggle through the articulation channels of interests could continue. Secondly, support from BM PAN, GMBI, STN, and other organizations in the form of moral support, legal assistance, movement assistance, and compensation for money and goods, which greatly helped in the success of the STTB in resolving conflicts. Third, the central government contributes to resolving conflicts, where the central government has more attention to agrarian conflicts by making agrarian reform strategies so that they can provide solutions to conflicts that occur. 


\section{References}

[1] Blair, L., 2012. Ring of Fire. Jakarta: Ufuk Press.

[2] Material of Land Disputes between the Community and PT Pertiwi Lestari in Karawang Regency, which was issued by the Karawang Regency Land Office in 2018.

[3] Sitepu, A., Studi Ilmu Politik. 2012. Jakarta: Graha Ilmu.

[4] interview with Budiono, Bureau of Public Relations of the Integrated Farmers Group of Telukjambe [1] Bersatu, on March 20, 2019, at 16:30 WIB, Karawang: Kampung Pasir Ipis.

[5] Interview with Inggar Permana, Executive Board of the National Mandate Enforcement, on March 24, 2019, at 15:10 WIB, Karawang: Wadas Village.

[6] Mas'oed, M., dan MacAndrews, C., 1986. Perbandingan Sistem Politik. Yogyakarta: Gadjah Mada University.

[7] Report on the Results of Panja Commission II Working Visit of the House of Representatives in Margakarya Village, Margajaya Village, and Wanajaya Village, Telukjambe Barat District, Karawang Regency on Monday 17 April 2017.

[8] Republic of Indonesia Law No. 5 of 1960 concerning Basic Rules for Agrarian Principles Part VIII Article 46.

[9] Rusmanto, J. Sosiologi Politik Gerakan Sosial dan Pengaruhnya Terhadap Studi Perlawanan. 2012. Palangkaraya: Zifatama Publishing.

[10] Interview with Deden, Chairperson of the Karawang Farmers Union, on March 23, 2019, at 14.30 WIB, Karawang: DPC PDIP Karawang.

[11] Interview with Dadi Mulyadi, Chair of LBH GMBI, on March 22, 2019, at 17:30 West Indonesia Time, Karawang: XO Cofee.

[12] Land Settlement and Conflict Resolution Agreement Between PT. Pertiwi Lestari and the Telukjambe Farmers Union United with the Land Handover in Tamansari Village, Pangkalan District, Karawang Regency on September 6, 2018.

[13] Interview with Wagito, Head of the Karawang BPN Problem Handling Section, on April 8, 2019, at 10:30 WIB, Karawang: Karawang BPN Office.

[14] Pribadi, T., Sistem Politik Indonesia. 2013. Tangerang Selatan: Universitas Terbuka.

[15] The National Strategy for the Implementation of Agrarian Reform 2016-2019 was published on 28 April 2016 by the Office of the Presidential Staff. 